\title{
Comparison of sewn fabric bending rigidities obtained by heart loop method: effects of different stitch types and seam directions
}

\author{
DOI: $10.35530 / \mathrm{IT} .071 .02 .1647$
}

\section{ABSTRACT - REZUMAT}

\section{Comparison of sewn fabric bending rigidities: effects of different stitch types and seam directions}

Sewing quality is an important factor that contributes to the overall quality of an end-product. Sewing quality compromises different components such as bending, seam strength, seam slippage, elasticity etc. Among these components, bending has a special importance because of causing changes in appearance, sensorial comfort and drape of a garment. Therefore, in this study, effects of stitch type and seam direction on the bending rigidities of sewn fabrics were evaluated and compared. A polyester woven fabric which is suitable for sportswear was sewn with three basic stitch types (lock stitch, chain stitch and overlock stitch), in 5 different directions (warp, weft, $30^{\circ}, 45^{\circ}$ and $60^{\circ}$ angles). As reference, samples without stitches were tested, too. Bending properties of samples were determined via heart loop method. According to the results, sewing increased the fabric bending rigidity. The degree of bending rigidity increment was dependent on the stitch type. Highest bending rigidity values were obtained for overlock stitched samples those were approximately 4 times higher when compared to non-sewn reference samples. Thickness of sewn parts was in accordance with the bending rigidity results. For oriented seams, bias sewing especially for $45^{\circ}$ oriented samples, showed the most advantageous bending results. This study showed the usability of heart loop method for sewn samples via consistent results for different stitch types and seam directions.

Keywords: bending rigidity, heart loop method, sewn fabrics, stitch type, seam direction.

Analiza comparativă a rigidității la încovoire a asamblărilor prin coasere: influența diferitelor tipuri de cusături și a direcțiilor de coasere

Calitatea asamblărilor prin coasere este un factor important care contribuie la calitatea generală a unui produs final. Calitatea asamblărilor prin coasere influențază diferite caracteristici, cum ar fi rezistența la încovoiere, rezistența cusăturii, elasticitatea etc. Printre aceste caracteristici, rezistența la încovoiere are o importanță deosebită deoarece influențează aspectul, confortul senzorial și drapajul unui produs de îmbrăcăminte. Astfel, în acest studiu, a fost evaluată și comparată influența tipului de cusătură și direcției de coasere asupra rigidității la încovoiere a materialelor textile asamblate. O țesătură din poliester care este destinată articolelor de îmbrăcăminte sport a fost asamblată cu trei tipuri de cusături de bază (cusătură simplă, cusătură lanț și cusătură de surfilare), în 5 direcții diferite (urzeală, bătătură, diagonal cu unghiuri de $30^{\circ}, 45^{\circ}$ și $60^{\circ}$ ). Ca referință, au fost testate și probe fără cusături. Rezistență la încovoiere a probelor a fost determinată prin metoda în buclă. Conform rezultatelor, asamblarea prin coasere determină creșterea rigidității la încovoiere a țesăturii. Gradul de rigiditate la încovoiere depinde de tipul de cusătură. Valorile cele mai ridicate ale rigidității la încovoiere au fost obținute pentru probele asamblate prin cusătură de surfilare, acestea fiind de aproximativ 4 ori mai mari în comparație cu probele de referință necusute. Grosimea pieselor asamblate a fost influențată similar cu rigiditatea la încovoiere. Cusăturile diagonale, în special pentru probele orientate la $45^{\circ}$, au prezentat cele mai mici valori pentru rezistența la încovoiere. Acest studiu a demonstrat utilizarea metodei în buclă pentru probele asamblate, prin rezultate importante pentru diferite tipuri de cusături și direcții de coasere.

Cuvinte-cheie: rigiditate la încovoiere, metoda în buclă, ţesături asamblate, tip de cusătură, direcţia de coasere

\section{INTRODUCTION}

Ready-to-wear end-products are obtained by sewing (stitching), bonding, welding or pressing the fabrics which were cut in certain dimensions and shapes [1]. Among the ready-to-wear assembling methods, stitching with a sewing thread is the most common and will have a continuing importance in the following decades.
Esthetical and in-use quality of a garment is mostly determined by the fabric quality. In addition, sewing quality is also an important factor that affects both the esthetic and functional properties of the end-product [2]. Sewing quality is related to seam appearance and seam performance that have the components such as seam strength, seam slippage, seam elasticity and recovery, seam puckering, softness, drape and resistance to abrasion $[1,3]$. In the literature 
effects of stitch density, seam direction, sewing thread properties, sewing thread tensions, sewing needle fineness, fabric type, washing etc. on the seam strength and seam slippage were studied, widely [4-19]. On the other hand, bending rigidity is another important factor that affects both the drape and form of the sewn fabrics. In the literature, there are some studies that evaluated the effects of stitch density [20-21], sewing thread type, sewing needle fineness [5], sewing thread tension [5], seam allowance [21-23], seam placement [23], seam direction (warp, weft, $45^{\circ}$ bias) [24], fabric thickness [22] and fabric type [20, 23] on the bending rigidity and drape of the sewn seams. As known, there are a variety of stitch types which can be preferred according to the fabric type, purpose of usage and end-use area. According to the knowledge of author, there is not any study focusing on the bending rigidities of fabrics sewn with different stitch types.

Generally, properties of sewn fabrics are tested in warp and weft directions. In spite of this, in real garment production, fabric pieces are frequently sewn together with different angles to warp or weft directions, as shown in figure 1.
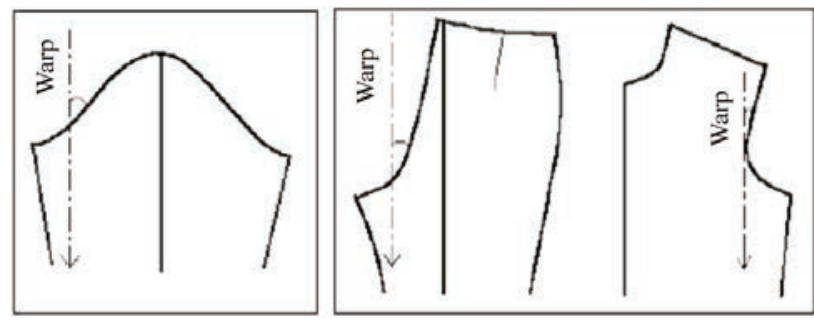

Fig. 1. Oriented seam lines in different garment pieces [9]

Straight or curved seams can be formed in yokes, darts, side seams, shoulders or armpits in different directions for several garment models. Bending rigidities in these oriented seams may change and impair the seam appearances by affecting the drape. Therefore, in this study, seams at different directions were formed and effect of seam direction on the bending rigidities of sewn fabrics was evaluated, too. By this way, the interaction of both seam direction and stitch type on the bending rigidity of sewn fabrics were evaluated. Also, different than the literature, sewn fabric bending rigidities were determined by heart loop method. Sewn samples form multilayer structures along the seam lines, which contain 3 fabric layers with the seam allowances. In addition, some curviness are formed on the short edges of samples because of the seams. These - curviness on the short edge and multilayered structure of test samples - may cause some mistakes during the readings of cantilever stiffness test. It is known that heart loop method can be used for the samples, which are not appropriate to cantilever test. In this study, to avoid from possible mistakes, heart loop method was applied for bending rigidity measurements of sewn samples instead of cantilever test.
Overall, the aim of this study was to determine the bending rigidities of sewn woven fabrics by heart loop method and compare the results in terms of stitch types and seam directions. For this purpose; lock stitch (stitch type 301, 2 yarn), chain stitch (stitch type 401, 2 yarn) and overlock stitch (stitch type 504, 3 yarn) were selected as they are the most used stitch types. These three stitches were sewn in 5 different directions; namely, warp weft, $30^{\circ}, 45^{\circ}$ and $60^{\circ}$ angles with weft direction. As the seam appearances and seam allowances in face and back of the fabric are different, bending rigidities of samples were determined for both face and back of the fabric and the mean bending rigidities for each sample type were calculated.

\section{MATERIALS AND METHODS}

\section{Materials}

Materials of this study are consisted of woven polyester fabric and polyester sewing thread. Woven fabric properties are given in table 1. Sewing thread is a Serafil fine (Amann Group) 100\% polyester sewing thread with ticket number 120.

\begin{tabular}{|l|c|}
\hline \multicolumn{2}{|c|}{ PROPERTIES OF POLYESTER FABRIC } \\
\hline Raw material & $\begin{array}{c}100 \% \text { polyester } \\
\text { multifilament yarn }\end{array}$ \\
\hline Woven fabric type & Plain weave \\
\hline Unit mass $\left(\mathrm{g} / \mathrm{m}^{2}\right)$ & 79.8 \\
\hline Thickness $(\mathrm{mm})$ & 0.15 \\
\hline Weft density (threads/cm) & 47 \\
\hline Warp density (threads/cm) & 76 \\
\hline
\end{tabular}

\section{Methods}

\section{Sample preparation}

For all seam directions and stitch types, stitch density was fixed at 5 stitches/cm and seam allowances were kept as $5 \mathrm{~mm}$. After sewing, all the seams were folded and ironed as shown in the back views in figure 2.

Samples were sewn with 3 main stitch types namely; lock stitch, chain stitch and overlock stitch. To make comparisons, reference fabrics with no seams were tested for their bending properties, too. All the samples were sewn with straight seams in 5 directions. These directions were consisted of warp, weft, $30^{\circ}$, $45^{\circ}$ and $60^{\circ}$ angles with weft direction. The experimental plan of the study is given in figure 3 . Sample dimensions were selected as $2.5 \mathrm{~cm} \times 25 \mathrm{~cm}$ according to standard. In order to eliminate the tension differences which may occur on the starting and finishing ends of the sewn samples, samples were prepared $10 \mathrm{~cm}$ longer than the last dimensions and cut from each ends before testing. Seams were placed in the middle of the samples along the longer edges. 


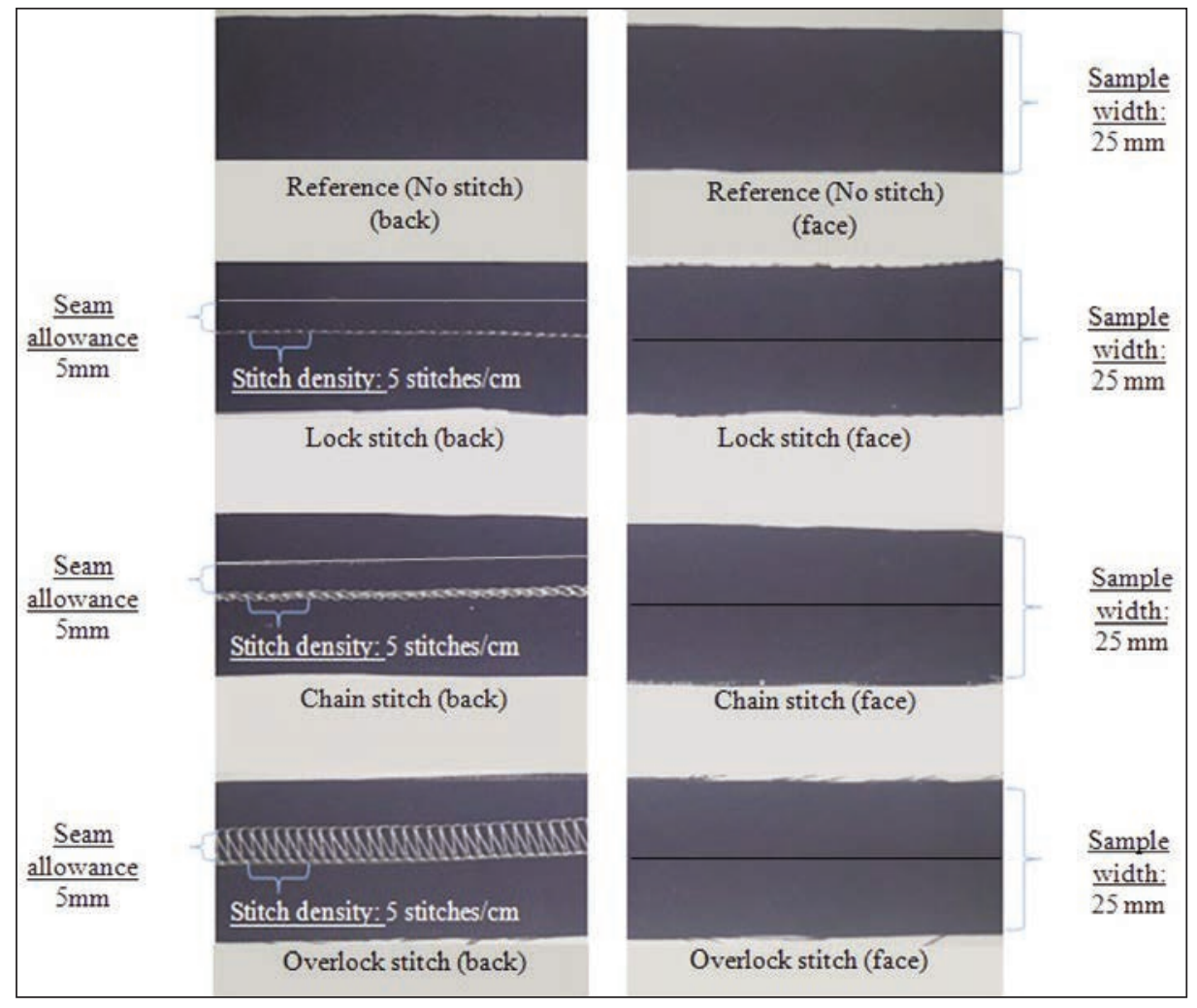

Fig. 2. Face and back side appearances of sewn samples

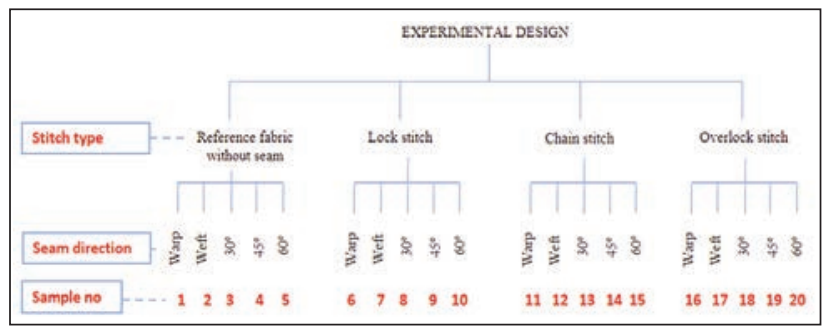

Fig. 3. Experimental plan and sample codes

All the samples were conditioned before testing at standard atmosphere conditions $\left(20 \pm 2^{\circ} \mathrm{C}, 65 \pm 5 \%\right.$ relative humidity) for 24 hours after ironing.

\section{Determination of the sample thicknesses}

Thickness of samples' sewn parts were determined according to TS 7128 EN ISO 5084 [25] standard by using James Heal RxB Cloth Thickness Tester. The pressure during measurements was $5 \mathrm{gf} / \mathrm{cm}^{2} .5$ measurements were taken for each stitch type and average values were calculated.

\section{Determination of the bending rigidities - Heart loop method}

Heart loop method is based on calculating the bending rigidity of a fabric strip which is formed to a heartshaped loop and hung vertically under its own mass. The length of the hung loop is measured and bending length and bending rigidity of the samples are calculated via this measurement (ASTM D 1388-14 [26]). Application of the heart loop method is harder than the cantilever method. But, heart loop method is preferred for the samples which are unsuitable for cantilever method, which tend to curl or twist.

As the sewn fabrics have a plied structure along the seam line, cantilever method may cause mistakes during determining the bending length. Therefore, bending rigidities of samples were determined according to ASTM D 1388-14 standard Option B - Heart Loop Method, in this study. Samples were fixed at two bars as shown in figure 4 in order to form a heart shaped loop. Test dimensions were $2.5 \mathrm{~cm} \times 20 \mathrm{~cm}$ because of the fastening of samples to the $2.5 \mathrm{~cm}$ wide bars.

Two measurements were performed for each sample. Firstly, the back face of the sample was in the outer side of the loop during the measurement. For the second measurement of the sample, face side of the sample was in the outer side of the loop. The obtained loop lengths were used to calculate the bending rigidities according to equation 1 . Bending length (c), $f_{2}(\theta)$ and $\theta$ were calculated according to equations 2, 3 and 4, respectively [27]. For each stitch type and seam direction, 4 samples were measured according to standard.

Fig. 4. Heart loop test apparatus and sample placement

Bending rigidity:

$$
G=1.421 \cdot 10^{-5} \cdot w \cdot c^{3}
$$

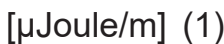$$
c=0.1337 \mathrm{~L} \cdot f_{2}(\theta)[\mathrm{cm}]
$$$$
f_{2}(\theta)=(\cos \theta / \tan \theta)^{1 / 3}
$$$$
\theta=32.85 \cdot[(I-0.1337 \mathrm{~L}) /(0.1337 \mathrm{~L})]\left[{ }^{\circ}\right]
$$

$L$ is strip length $(\mathrm{cm}), w-$ unit mass $\left(\mathrm{g} / \mathrm{m}^{2}\right)$ and $I-$ loop length $(\mathrm{cm})$.

\section{RESULTS}

\section{Thickness results}

Samples were consisted of fabrics sewn with lock stitch, chain stitch and overlock stitch. Also reference samples without stitches were measured, too. In the sewn places, an additional thickness was occurred 
because of sewing threads and folded fabrics. These thickness increments might contribute to bending rigidity changes of the sewn samples.

Mean thickness values and standard deviations of samples are given in table 2. Also, samples' thickness values are shown graphically in figure 5 .

Table 2

THICKNESS OF SEWN PARTS OF SAMPLES AND REFERENCE FABRIC

\begin{tabular}{|c|c|c|}
\hline Sample & $\begin{array}{c}\text { Mean } \\
(\mathbf{m m})\end{array}$ & $\begin{array}{c}\text { Standard deviation } \\
(\mathbf{m m})\end{array}$ \\
\hline $\begin{array}{c}\text { Reference fabric } \\
\text { (without seam) }\end{array}$ & 0.15 & 0.008944 \\
\hline Lock Stitch & 0.65 & 0.040415 \\
\hline Chain Stitch & 0.81 & 0.017321 \\
\hline Overlock Stitch & 1.02 & 0.093229 \\
\hline
\end{tabular}

According to test results given in table 2, thickness of sewn parts of samples increased 4 to 7 times when compared to reference fabric. Thickness of reference fabric was $0.15 \mathrm{~mm}$ while thickness of lock stitched, chain stitched and overlock stitched samples were $0.65,0.81$ and $1.02 \mathrm{~mm}$, respectively. The overlock stitch with the highest number of sewing threads which covered $5 \mathrm{~mm}$ seam allowance, had higher thickness when compared to lock stitch and chain stitch.

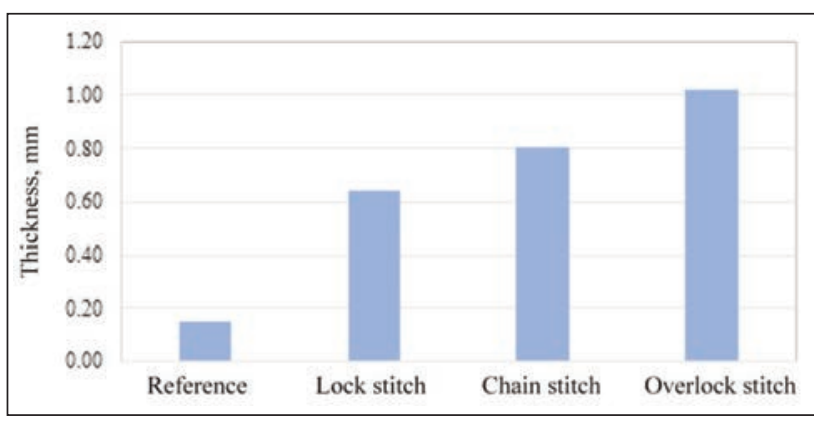

Fig. 5. Thickness values of samples

\section{Bending rigidity and bending length results}

Bending length of samples are given in table 3 and figure 6 , with respect to the face side, back side and the mean of the two sides. Bending rigidities of face and back sides of the samples represent the behavior of bent garment from the outer and inner faces.

Bending lengths were between $1.18-2.10 \mathrm{~cm}$ for the face of samples and 1.13-2.20 cm for the back of samples. In general, bending lengths calculated for face and back sides of samples were very close to each other. When the mean values were calculated for each sample by using the results of face and back sides, the bending lengths were obtained between 1.16 and $2.15 \mathrm{~cm}$ for all samples. The bending lengths were the lowest for reference samples and highest for the samples sewn with overlock stitch

Table 3

BENDING LENGTH RESULTS OF SAMPLES BELONGING TO FACE AND BACK SIDES AND MEAN VALUES

\begin{tabular}{|c|c|c|c|c|c|c|c|}
\hline \multirow{3}{*}{\multicolumn{2}{|c|}{ Sample }} & \multicolumn{6}{|c|}{ Bending length (cm) } \\
\hline & & \multicolumn{2}{|c|}{ FACE SIDE } & \multicolumn{2}{|c|}{ BACK SIDE } & \multicolumn{2}{|c|}{ MEAN } \\
\hline & & Mean & St. Dev. & Mean & St. Dev. & Mean & St. Dev. \\
\hline \multirow{5}{*}{ Reference fabric } & Warp & 1.39 & 0.03 & 1.42 & 0.05 & 1.40 & 0.04 \\
\hline & Weft & 1.33 & 0.05 & 1.35 & 0.03 & 1.34 & 0.04 \\
\hline & $30^{\circ}$ & 1.19 & 0.11 & 1.13 & 0.06 & 1.16 & 0.09 \\
\hline & $45^{\circ}$ & 1.18 & 0.06 & 1.21 & 0.00 & 1.19 & 0.04 \\
\hline & $60^{\circ}$ & 1.19 & 0.06 & 1.22 & 0.03 & 1.20 & 0.04 \\
\hline \multirow{5}{*}{ Lock stitch } & Warp & 1.92 & 0.13 & 1.91 & 0.12 & 1.92 & 0.12 \\
\hline & Weft & 1.89 & 0.11 & 1.80 & 0.15 & 1.84 & 0.13 \\
\hline & $30^{\circ}$ & 1.81 & 0.08 & 1.75 & 0.09 & 1.78 & 0.09 \\
\hline & $45^{\circ}$ & 1.59 & 0.11 & 1.51 & 0.03 & 1.55 & 0.09 \\
\hline & $60^{\circ}$ & 1.66 & 0.03 & 1.60 & 0.03 & 1.63 & 0.04 \\
\hline \multirow{5}{*}{ Chain stitch } & Warp & 2.02 & 0.10 & 2.06 & 0.12 & 2.04 & 0.10 \\
\hline & Weft & 1.99 & 0.14 & 2.04 & 0.10 & 2.01 & 0.12 \\
\hline & $30^{\circ}$ & 1.90 & 0.09 & 1.85 & 0.07 & 1.87 & 0.08 \\
\hline & $45^{\circ}$ & 1.58 & 0.05 & 1.51 & 0.15 & 1.54 & 0.11 \\
\hline & $60^{\circ}$ & 1.72 & 0.09 & 1.71 & 0.05 & 1.71 & 0.07 \\
\hline \multirow{5}{*}{ Overlock stitch } & Warp & 2.10 & 0.07 & 2.20 & 0.07 & 2.15 & 0.10 \\
\hline & Weft & 2.05 & 0.11 & 2.04 & 0.06 & 2.04 & 0.12 \\
\hline & $30^{\circ}$ & 1.82 & 0.07 & 1.69 & 0.11 & 1.76 & 0.08 \\
\hline & $45^{\circ}$ & 1.67 & 0.03 & 1.51 & 0.03 & 1.59 & 0.11 \\
\hline & $60^{\circ}$ & 1.71 & 0.06 & 1.71 & 0.05 & 1.71 & 0.07 \\
\hline
\end{tabular}




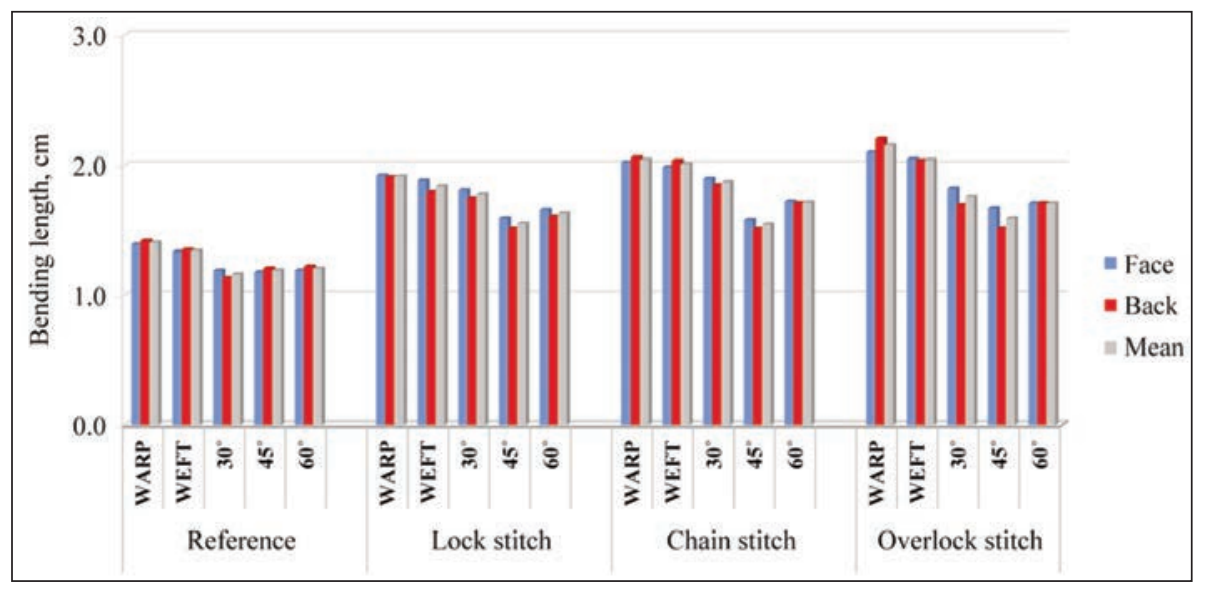

Fig. 6. Bending lengths of samples
The mean bending rigidities of all samples were between 1.80 and $11.30 \mu \mathrm{J} / \mathrm{m}$. The lowest bending rigidities were obtained for reference samples without sewing and this is valid for all testing directions (warp, weft, $30^{\circ}$, $45^{\circ}$ and $60^{\circ}$ ). For sewn samples, bending rigidity values were 2.2 to 4.2 times higher when compared to reference samples. As for the thickness results, the highest bending rigidities were obtained for overlock stitched samples and they were followed by type. Highest bending lengths were obtained for the samples in warp direction while lowest values were obtained for the samples sewn in $45^{\circ}$ direction.

Bending rigidities of samples are given in table 4 . Bending rigidities of samples were 1.85-10.51 $\mu \mathrm{J} / \mathrm{m}$ for face of the samples and 1.65-12.08 $\mu \mathrm{J} / \mathrm{m}$ for the back sides of the samples. As third power of the bending length (equation 1) was used to calculate the bending rigidity values, the differences between the face and back sides of the samples were more prominent for bending rigidities when compared to bending lengths. the chain stitched and lock stitched samples for all directions. The increment of bending rigidities dependent on the stitch type was higher for the samples sewn in $30^{\circ}$ direction.

Bending rigidity differences with respect to seam direction were obtained similar for all stitch types (lock, chain, overlock). For both reference samples and sewn samples, highest bending rigidity results were obtained in warp direction and they were followed by the weft direction. For the bias sewing, the lowest bending rigidity values were obtained for the samples sewn in $45^{\circ}$ direction. The samples sewn in

Table 4

BENDING RIGIDITY RESULTS OF SAMPLES BELONGING TO FACE AND BACK SIDES AND MEAN VALUES

\begin{tabular}{|c|c|c|c|c|c|c|c|}
\hline \multirow{3}{*}{ Sampl } & & \multicolumn{6}{|c|}{ Bending rigidity $(\mu \mathrm{J} / \mathrm{m})$} \\
\hline & & \multicolumn{2}{|c|}{ FACE SIDE } & \multicolumn{2}{|c|}{ BACK SIDE } & \multicolumn{2}{|c|}{ MEAN } \\
\hline & & Mean & St. Dev. & Mean & St. Dev. & Mean & St. Dev. \\
\hline \multirow{5}{*}{ Reference fabric } & Warp & 3.04 & 0.18 & 3.23 & 0.36 & 3.14 & 0.28 \\
\hline & Weft & 2.70 & 0.32 & 2.78 & 0.20 & 2.74 & 0.25 \\
\hline & $30^{\circ}$ & 1.94 & 0.50 & 1.65 & 0.25 & 1.80 & 0.40 \\
\hline & $45^{\circ}$ & 1.85 & 0.27 & 1.98 & 0.00 & 1.92 & 0.19 \\
\hline & $60^{\circ}$ & 1.92 & 0.27 & 2.06 & 0.15 & 1.99 & 0.22 \\
\hline \multirow{5}{*}{ Lock stitch } & Warp & 8.15 & 1.63 & 7.97 & 1.43 & 8.06 & 1.42 \\
\hline & Weft & 7.66 & 1.34 & 6.67 & 1.65 & 7.16 & 1.49 \\
\hline & $30^{\circ}$ & 6.74 & 0.82 & 6.07 & 0.97 & 6.41 & 0.91 \\
\hline & $45^{\circ}$ & 4.61 & 1.01 & 3.91 & 0.24 & 4.26 & 0.78 \\
\hline & $60^{\circ}$ & 5.15 & 0.25 & 4.68 & 0.23 & 4.91 & 0.34 \\
\hline \multirow{5}{*}{ Chain stitch } & Warp & 9.44 & 1.36 & 10.00 & 1.66 & 9.72 & 1.44 \\
\hline & Weft & 8.98 & 1.88 & 9.62 & 1.43 & 9.30 & 1.59 \\
\hline & $30^{\circ}$ & 7.79 & 1.13 & 7.17 & 0.85 & 7.48 & 0.98 \\
\hline & $45^{\circ}$ & 4.46 & 0.43 & 3.99 & 1.20 & 4.22 & 0.87 \\
\hline & $60^{\circ}$ & 5.80 & 0.90 & 5.65 & 0.48 & 5.73 & 0.67 \\
\hline \multirow{5}{*}{ Overlock stitch } & Warp & 10.51 & 1.09 & 12.08 & 1.14 & 11.30 & 1.33 \\
\hline & Weft & 9.81 & 1.60 & 9.59 & 0.87 & 9.70 & 1.20 \\
\hline & $30^{\circ}$ & 6.88 & 0.74 & 5.56 & 1.05 & 6.22 & 1.10 \\
\hline & $45^{\circ}$ & 5.27 & 0.28 & 3.91 & 0.24 & 4.59 & 0.76 \\
\hline & $60^{\circ}$ & 5.66 & 0.65 & 5.65 & 0.48 & 5.66 & 0.53 \\
\hline
\end{tabular}




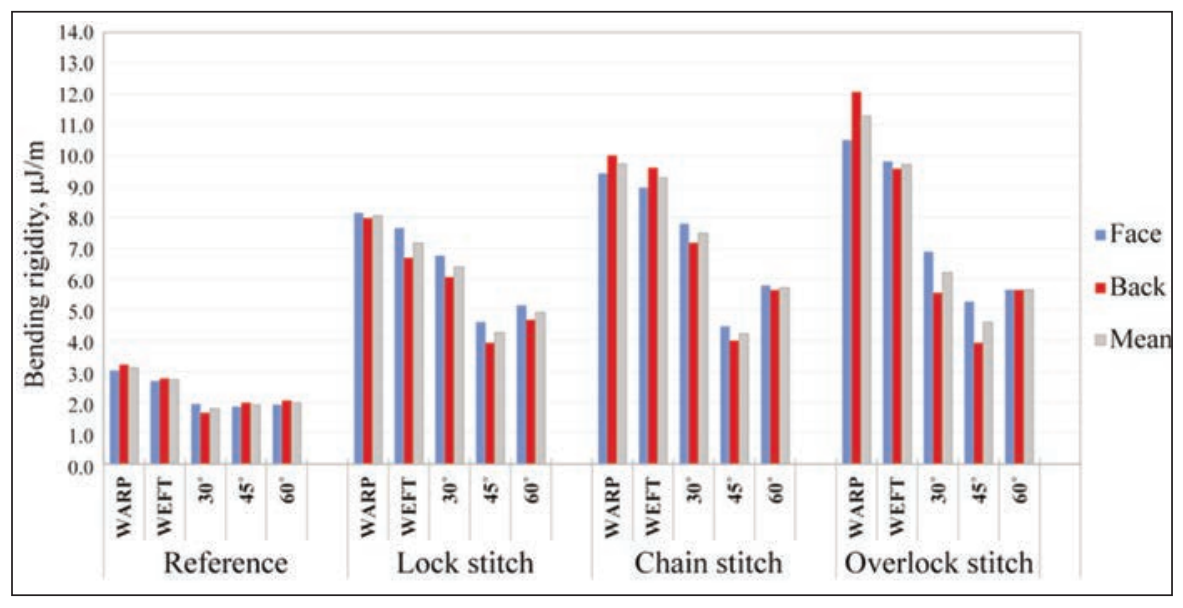

Fig. 7. Bending rigidities of samples followed by the chain stitched and lock stitched samples. From the literature, it is known that chain and overlock stitches are more flexible stitch types than lock stitch $[1,3]$. These contrary results in bending rigidity may be related to sewn places' thicknesses. Bending rigidity results was in accordance with the thickness results, in this study. The higher the sewn sample thickness, the higher the bending rigidity was obtained from the samples.

The orientation of the seams

$30^{\circ}$ angle had higher bending rigidities when compared to samples sewn in $60^{\circ}$ angle. The bending rigidity differences for different directions may be related to crimp ratios and the mechanical properties of the warp and the weft yarns [28].

\section{DISCUSSION}

In this study, thickness and bending rigidities of sewn samples were determined and results were compared with respect to stitch type and seam direction. At all, 3 different stitch types (lock, chain and overlock stitches) and 5 different seam directions (warp, weft, $30^{\circ}, 45^{\circ}$ and $60^{\circ}$ ) were formed and 20 different samples were obtained including reference samples. Bending rigidities of samples were determined via heart loop method as an alternative to cantilever method.

According to results, sewing increased the fabric bending rigidity for all stitch types and seam directions. Among the sewn samples, bending rigidity was the highest for overlock stitched samples and it was affected the bending properties. Seams in bias directions exhibited lower bending rigidity results. This indicates that, bias sewing may help to improve the appearance, drape and mobility comfort of an endproduct by lowering the bending rigidity.

In this study, bending rigidity values were calculated for both face and back sides of the samples, individually. Then the mean bending rigidities were calculated for each sample type. According to the results, bending length and bending rigidity values were very close to each other for the 2 sides. The order of the bending rigidity values did not change with respect to face or back of the samples.

Overall, this study helps to understand how the bending behaviors of sewn samples change with respect to different stitches and seam directions. Also, the usability of heart loop method is shown by consistent results of systematically produced samples. This study is limited by the base fabric which is a very thin woven fabric suitable for sportswear. The study may be extended by using thicker fabrics and sewing thread types for other application areas.

\section{REFERENCES}

[1] Kurumer, G., Konfeksiyon uretimi ve teknolojisi (2 $2^{\text {nd }}$ Press), Izmir: Printer Ofset Matbaacılık, 2012

[2] Okur, A., Tekstil materyallerinde mukavemet testleri, Izmir: DEU Muhendislik Fakultesi Yayınları, 2002

[3] Jones, I., Stylios, G.K. (Eds.), Joining textiles: Principles and applications, Elsevier, 2013

[4] Namiranian, R., Shaikhzadeh Najar, S., Etrati, S.M., Manich, A.M., Seam slippage and seam strength behavior of elastic woven fabrics under static loading, In: Indian Journal of Fibre \& Textile Research (IJFTR), 2014, 39, 3, 221-229

[5] Choudhary, A.K., Goel, A., Effect of some fabric and sewing conditions on apparel seam characteristics, In: Journal of Textiles, 2013, 2013, 1-7

[6] Gurarda, A., Investigation of the seam performance of PET/nylon-elastane woven fabrics, In: Textile Research Journal, 2008, 78, 1, 21-27

[7] Bharani, M., Shiyamaladevi, P.S.S., Mahendra Gowda, R.V., Characterization of seam strength and seam slippage on cotton fabric with woven structures and finish, In: Research Journal of Engineering Sciences, 2012, 1, 2, 41-50

[8] Sular, V., Mesegul, C., Kefsiz, H., Seki, Y., A comparative study on seam performance of cotton and polyester woven fabrics, In: The Journal of the Textile Institute, 2015, 106, 1, 19-30

[9] Citoglu, F., Kaya, G., Dikis iplik ozelliklerinin ve dikis sıkliklarinin farklı dikis acilarında dikis mukavemeti uzerine etkileri, In: Tekstil ve Konfeksiyon, 2011, 21, 2, 182-188

[10] Xin, L.U., Effect of sewing form and parameters on seam strength of silk fabric, In: Shanghai Textile Science \& Technology, 2010, 5, 17

industroia textillă 
[11] Ozdemir, H, Yavuzkasap, D., The effects of yarn and fabric structural parameters on the seam slippage, abrasion and pilling properties of double woven upholstery fabrics, In: Industria Textila, 2012, 63, 6, 307-314

[12] Yesilpinar, S., Bahar, S., The effect of sewing and washing processes on the seam strength of denim trousers, In: AATCC review, 2007, 7, 10, 27-31

[13] Yeşilpınar, S., Analysis of the performance of sewing threads manufactured from conventional and compact ringspun yarns, In: Fibres \& Textiles in Eastern Europe, 2006, 14, 2, 20-23

[14] Gribaa, S., Ben Amar, S., Dogui, A., Influence of sewing parameters upon the tensile behavior of textile assembly, In: International journal of clothing science and Technology, 2006, 18, 4, 235-246

[15] Chowdhary, U., Poynor, D., Impact of stitch density on seam strength, seam elongation, and seam efficiency, In: International Journal of Consumer Studies, 2006, 30, 6, 561-568

[16] Tarafder, N., Karmakar, R., Mondal, M., The effect of stitch density on seam performance of garments stitched from plain and twill fabrics, In: Man-Made Textiles in India, 2007, 50, 8, 298-302

[17] Mukhopadhyay, A., Sikka, M., Karmakar, A.K., Impact of laundering on the seam tensile properties of suiting fabric, In: International Journal of Clothing Science and Technology, 2004, 16, 4, 394-403

[18] Brain, D.H., The prediction of strengths of lock stitch seams in woven fabrics, In: Journal of the Textile Institute, 1970, 61, 10, 493-505

[19] Günaydin, G.K., Effect of coating ratio and weft density on some physical properties of upholstery fabrics, In: Industria Textila, 2019, 70, 4, 379-385, http://doi.org/10.35530/IT.070.04.1695

[20] Megeid, Z.A., Ezzat, M.M., Elzaki, G.M., Studying the bending stiffness of polyester/linen fabric seams with different structures, In: International Journal of ChemTech Research, 2016, 9, 4, 1-6

[21] Gurarda, A., Dikiş parametrelerinin dokuma kumaşların eğilme dayanımı üzerine etkileri, In: Tekstil ve Konfeksiyon, 2009, 19, 3, 242-247

[22] Hu, J., Chung, S., Bending behavior of woven fabrics with vertical seams, In: Textile Research Journal, 2000, 70, 2, 148-153

[23] Chung, S., Hu, J., Lo, M., Effect of seam allowance of a plain seam on bending of woven fabrics, In: Research Journal of Textile and Apparel, 1999, 3, 1, 54-64

[24] Mahar, T.J., Ajiki, I., Postle, R., Fabric mechanical and physical properties relevant to clothing manufacture - Part 2: Structural balance, breaking elongation and curvature of seams, In: International Journal of Clothing Science and Technology, 1989, 1, 2, 5-10

[25] TS 7128 EN ISO 5084 Tekstil-Tekstil ve tekstil mamullerinin kalinlik tayini. Ankara: Turk Standartları Enstitusu, 1998

[26] ASTM D1388 Standard test method for stiffness of fabrics. Option B, Heart loop test. West Conshohocken: ASTM International, 2018

[27] Hu, J., Structure and mechanics of woven fabrics. Cambridge: Woodhead Publishing, 2004

[28] Gupta, B.S., Leek, F.J., Barker, R.L., Buchanan, D.R., Little, T.J., Directional variations in fabric properties and seam quality, In: International Journal of Clothing Science and Technology, 1992, 4, 2/3, 71-78

Author:

KARA SUKRAN

Dokuz Eylul University, Engineering Faculty, Textile Engineering Department, Tınaztepe Campus, Buca, 35397, Izmir, Turkey

Corresponding author:

KARA SUKRAN

e-mail: sukran.kara@deu.edu.tr 